\title{
Effects of Aqueous Bryophyllum pinnatum Leaf Extract on Haematological, Renal and Sperm Indices in Wistar Rats
}

\section{J. S. APRIOKU*AND I. IGBE}

Department of Experimental Pharmacology and Toxicology, Faculty of Pharmaceutical Sciences, University of Port Harcourt, PMB 5323, East-West Road, Choba, Rivers State, ${ }^{1}$ Department of Pharmacology and Toxicology, Faculty of Pharmacy, University of Benin, Benin City, Nigeria

Aprioku and Ighodaro: Toxicity Profile of Bryophyllum pinnatum Leaf Extract

\begin{abstract}
Bryophyllum pinnatum is a perennial herb, widely used in the treatment of several conditions in folklore medicine. The effects of sub-acute treatment of the aqueous extract of $B$. pinnatum leaf on haematological, renal and testicular functions were investigated in the Wistar rat. Adult rats were randomly distributed into three groups of six rats each and administered $0,62.5$ or $125 \mathrm{mg} / \mathrm{kg}$ of extract daily for 28 days by oral gavage. Blood levels of urea, creatinine and haematological parameters, as well as epididymal sperm parameters were measured. Kidney and testis of animals were removed and organ weight to body weight ratios were determined. Histology of the organs was also analysed. The extract elevated white blood cell count, reduced neutrophil count $(\mathrm{P}<0.05)$ without affecting lymphocyte count and packed cell volume, when compared to control. The extract did not alter sperm count, motility, morphology and viability as well as blood urea and creatinine levels. The extract did not alter histology and relative weights of the kidney and testis. It can be concluded that sub-acute administration of the aqueous extract of $B$. pinnatum did not produce any renal and testicular toxicity, but may depress neutrophil action.
\end{abstract}

Key words: Bryophyllum pinnatum, flavonoids, neutrophil, sub-acute, testis

Bryophyllum pinnatum (Lam.), syn. Kalanchoe pinnata (Lam.), and B. calycinum (Salisb.) is a widely distributed perennial medicinal herb. It is native to Madagascar, but has been naturalized in several other regions, including the temperate regions of Asia, Australia, and New Zealand. B. pinnatum is known by some common names including, life plant, air plant, maternity plant, love plant, miracle leaf, cathedral bells, mother of thousands, leaf of resurrection plant, and Lao di Sheng gen. The plant is locally called "Never Die" in Nigeria, and is very popular in folklore medicine. It has been used for the treatment of a variety of conditions in tropical America, India, China, Australia and Africa, including, rheumatism, body pain, arthritis, heartburn, skin ulcers, peptic ulcer, diabetes mellitus, microbial infections, and hypertension ${ }^{[1-6]}$. In Nigeria, the plant is particularly known for its effective wound healing properties and detachment of the umbilicus of infants. Pharmacological studies on $B$. pinnatum reported several biological activities some of which could authenticate the plant's traditional uses including, immunomodulatory ${ }^{[7]}$, CNS depressant ${ }^{[8]}$, analgesic,

${ }^{*}$ Address for correspondence E-mail: sydaprio@yahoo.com antiinflammatory ${ }^{[9]}$, antimicrobia ${ }^{[10,11]}$, antitumor ${ }^{[12]}$, antiulcer $^{[13]}$ insecticidal ${ }^{[14]}$, antidiabetic $^{[15]}$, anticonvulsant ${ }^{[16]}$, antioxidant ${ }^{[17]}$, and antihypertensive properties $^{[18]}$. Studies have also reported a wide range of active phytochemicals such as alkaloids, triterpenes, glycosides ${ }^{[18]}$, flavonoids ${ }^{[16,19]}$, steroids ${ }^{[9]}$, bufadienolides ${ }^{[20]}$, lipids and organic acids ${ }^{[21]}$. These compounds have been considered to be responsible for the plant's diverse pharmacological activities.

Although, folklore claims of many herbal remedies are yet to be authenticated scientifically, $B$. pinnatum has been reasonably studied with justification of most of the claims. This has enhanced the promotion of the use of $B$. pinnatum and other plants either as alternatives or to complement orthodox medicines. Additionally,

This is an open access article distributed under the terms of the Creative Commons Attribution-NonCommercial-ShareAlike 3.0 License, which allows others to remix, tweak, and build upon the work non-commercially, as long as the author is credited and the new creations are licensed under the identical terms

Accepted 07 May 2017

Revised 07 January 2017

Received 07 July 2016

Indian J Pharm Sci 2017;79(4):521-526 
cost of orthodox medications and the development of resistance to most orthodox chemotherapeutic agents has resulted in the use of herbal medications like B. pinnatum leaf as alternatives, especially in underdeveloped countries ${ }^{[22,23]}$. In many cases, $B$. pinnatum leaves were soaked in cold water overnight, boiled in water, squeezed or roasted and the extracts obtained are used to treat fevers, headache, joint pains, arthritis, body pains, asthma, cancers, tonsillitis, diarrhoea, cough, and many other conditions ${ }^{[2-4,6]}$. Aside from the earlier stated factors, $B$. pinnatum is also a popular herbal medicine due to local belief that natural extracts are free of adverse effects ${ }^{[23,24]}$. This makes safety evaluation of frequently used medicinal plants imperative. The present study was thus aimed at investigating the effects of sub-acute administration of aqueous $B$. pinnatum leaf extract on haematological, renal and testicular indices in rats.

\section{MATERIALS AND METHODS}

Fresh leaves of $B$. pinnatum were collected from the botanical garden of the University of Port Harcourt, Port Harcourt. The leaves were air dried, pulverized $(400 \mathrm{~g})$ and extracted exhaustively in distilled water for $72 \mathrm{~h}$ by cold maceration. The filtrate was subsequently evaporated to obtain the dry extract using a rotary evaporator. The dry extract was weighed $(28 \mathrm{~g})$ and the percentage yield was determined (7\%). The extract was then tested for the presence of phytochemicals using standard methods ${ }^{[25]}$.

\section{Experimental animals:}

Eighteen adult male Wistar rats of $12 \mathrm{w}$ of age, obtained from the animal house of the University of Port Harcourt, Nigeria were used for the study. The animals were given standard rodent chow and clean drinking water ad libitum. The animals were kept in a well-ventilated room with a $12 \mathrm{~h}$ light/dark cycle at room temperature. All animal experiments were approved by the Animal Research Ethics Committee of the University, in accordance to the guide for care and use of laboratory animals ${ }^{[26]}$.

\section{Experimental design:}

The animals were randomly distributed into three groups of 6 rats per group. The first and second groups were administered 62.5 and $125 \mathrm{mg} / \mathrm{kg}$ of aqueous B. pinnatum leaf extract by oral gavage $(1 \mathrm{ml} / \mathrm{kg})$ daily for $28 \mathrm{~d}$, respectively. The animals in the third group served as control and were given only distilled water $(1 \mathrm{ml} / \mathrm{kg})$ daily for $28 \mathrm{~d}$. At the end of extract administration, the rats were sacrificed by cervical dislocation under deep diethyl ether anaesthesia. Blood samples were collected separately into labelled plain and EDTA bottles, for measurement of urea, creatinine and haematological parameters, respectively. Animals were dissected and sperm was extracted from cauda epididymis for sperm analysis. The kidney and testis were also removed, weighed and routinely processed for histological evaluation.

Blood sample was centrifuged for $15 \mathrm{~min}$ at $3000 \mathrm{rpm}$ to separate serum and the serum was stored at $-80^{\circ}$. Serum levels of urea and creatinine were then assayed. Creatinine was measured using alkaline picrate method $^{[27]}$, and urea was assayed using urease-Berthelot method $^{[28]}$. Whole blood collected into EDTA bottle was used to assay packed cell volume (PCV), and total white blood cell (WBC), lymphocyte and neutrophil counts, using standard laboratory techniques ${ }^{[29]}$.

\section{Sperm analysis:}

The method of Amelar et al. ${ }^{[30]}$ was used in collecting sperm cells from the epididymis. Briefly, the testis was excised and the caudal epididymis was carefully isolated and placed in a petri dish containing $3 \mathrm{ml}$ of sodium bicarbonate $\left(\mathrm{NaHCO}_{3}\right)$ buffered Tyrodes' solution. Several $(1 \mathrm{~mm})$ incisions were made on it and sperm was gently drawn into a plastic transfer pipette and transferred into $5 \mathrm{ml}$ test tubes and vigorously shaken for homogeneity and dispersal of sperm cells. Sperm was then analysed to determine sperm motility, sperm count, percentage of abnormal sperm cells (sperm morphology) and percentage of viable sperm cells (sperm viability) following standard procedures ${ }^{[29]}$.

\section{Histopathological analysis:}

The kidney and testicular tissues were fixed in $10 \%$ buffered formalin. The tissues were embedded in paraffin and tissue sections $(5-7 \mu \mathrm{m})$ were stained with haematoxylin and eosin $(\mathrm{H}$ and $\mathrm{E})$ and examined with light microscope (Nikon Eclipse E400). All alterations from the normal structures were registered and histopathological changes between control and experimental rats were noted. The images were photographed with an Olympus Model BX51 microscope at a magnification of 400x.

\section{Statistical analysis:}

The results are presented as mean \pm SEM for each group. Differences among groups were analysed using one-way analysis of variance (ANOVA) followed by Dunette's multiple comparison test. Data were 
analysed using GraphPad Prism Version 5 and values were considered significant at $\mathrm{P}<0.05$.

\section{RESULTS AND DISCUSSION}

The doses used in the present study were selected with the specific aim of evaluating the effect of lower biologically active doses of the extract. The $\mathrm{LD}_{50}$ of $B$. pinnatum (the aqueous extract) has been reported to be $1.8 \mathrm{~g} / \mathrm{kg}$ (i.p.) in rats; while no obvious toxicological signs were observed at $5 \mathrm{~g} / \mathrm{kg}$ dose administered orally ${ }^{[31]}$. In many previous animal studies, doses of $B$. pinnatum used range from $150 \mathrm{mg} / \mathrm{kg}$ to as high as $2000 \mathrm{mg} / \mathrm{kg}$. The toxicological profile of subacute treatment of the aqueous extract of $B$. pinnatum leaf $(62.5-125 \mathrm{mg} / \mathrm{kg})$ on renal, haematological and testicular indices in the rat is herein reported.

Phytochemical analysis of aqueous $B$. pinnatum leaf extract showed the presence of alkaloids, carbohydrates, flavonoids, saponins, triterpenoid, tannins/phenols, anthraquinone and steroids (Table 1). Administration of the extract did not cause any significant change $(\mathrm{P}>0.05)$ in serum levels of urea and creatinine when compared to the control (Table 2). Sperm counts and motility obtained in extract treated rats were not significantly different $(\mathrm{P}>0.05)$ from those of control animals (Table 3). Percent viable sperms (sperm viability) and abnormal sperms (sperm morphology) in extract-treated rats were also not altered, when compared to control values (Table 3 ).

TABLE 1: PHYTOCHEMICAL CONSTITUENTS OF AQUEOUS B. PINNATUM LEAF EXTRACT

\begin{tabular}{lc}
\hline Phytochemical constituents & Results \\
\hline Alkaloids & + \\
Carbohydrates & + \\
Flavonoids & + \\
Saponins & + \\
Triterpenoid & + \\
Tannins/phenols & + \\
Cardenolide & - \\
Anthraquinone & + \\
Steroids & + \\
\hline
\end{tabular}

‘+' Indicates present, '-' indicates absent

TABLE 2: EFFECTS OF SUB-ACUTE ADMINISTRATION OF AQUEOUS B. PINNATUM LEAF EXTRACT ON SERUM LEVELS OF UREA AND CREATININE IN WISTAR RATS

\begin{tabular}{lcc}
\hline Dose & Urea $(\mathrm{mmol} / \mathrm{l})$ & Creatinine $(\mu \mathrm{mol} / \mathrm{l})$ \\
\hline Control & $3.38 \pm 1.2$ & $32.00 \pm 3.67$ \\
$62.5 \mathrm{mg} / \mathrm{kg}$ & $3.37 \pm 1.41$ & $36.00 \pm 4.50$ \\
$125 \mathrm{mg} / \mathrm{kg}$ & $3.18 \pm 1.32$ & $35.50 \pm 2.57$ \\
\hline
\end{tabular}

Data expressed as mean \pm SEM, $\mathrm{n}=6$ animals per group
TABLE 3: EFFECTS OF SUB-ACUTE ADMINISTRATION OF AQUEOUS B. PINNATUM LEAF EXTRACT ON SPERM PARAMETERS IN WISTAR RATS

\begin{tabular}{lcccc}
\hline $\begin{array}{l}\text { Dose } \\
(\mathrm{mg} / \mathrm{kg})\end{array}$ & $\begin{array}{c}\text { Sperm } \\
\text { count } \\
\left(\times 10^{6}\right)\end{array}$ & $\begin{array}{c}\text { Sperm } \\
\text { motility } \\
(\%)\end{array}$ & $\begin{array}{c}\text { Sperm } \\
\text { viability } \\
(\%)\end{array}$ & $\begin{array}{c}\text { Sperm } \\
\text { morphology } \\
(\%)\end{array}$ \\
\hline Control & $63.83 \pm 5.02$ & $60.83 \pm 3.96$ & $70.25 \pm 6.18$ & $9.17 \pm 0.83$ \\
62.5 & $58.50 \pm 4.77$ & $57.50 \pm 3.35$ & $54.78 \pm 3.06$ & $6.67 \pm 1.05$ \\
125 & $65.83 \pm 2.87$ & $51.67 \pm 2.79$ & $62.27 \pm 1.78$ & $7.50 \pm 1.12$ \\
\hline
\end{tabular}

Data expressed as mean \pm SEM, $n=6$ animals per group

The results indicated that $B$. pinnatum administration would have no adverse effect on the kidney over the time and dose range used in this study as serum levels of urea and creatinine remained unchanged after treatment with the extract. Organ-to-body weight ratio is a useful indicator often employed in the assessment of organ toxicity ${ }^{[32]}$. There was no significant $(\mathrm{P}>0.05)$ change in kidney-to-body weight-ratio in all extract treated when compared to control rats (Table 4), neither did the plant cause any alteration in the micro structure of the kidney. Kidneys of treated and control rats showed normal architecture and structure with numerous glomeruli and tubules, and blood vessels lined by endothelial cells (fig. 1A, B and C). The implication of this observation was that sub-acute treatment of the plant extract had no adverse effect on the kidney, showing a positive correlation with the biochemical parameters measured. Previous studies have reported that aqueous extract of Kalanchoe pinnata (B. pinnatum) possessed protective effects on chemical-induced nephrotoxicity ${ }^{[33]}$.

The testis is highly susceptible to toxicity by chemicals and many medicinal plants have been reported to adversely affect testicular function in animals ${ }^{[34,35]}$. In the present study, the plant had no effect on sperm count, motility, morphology and viability (Table 3 ). Additionally, testes of control and extract-treated rats showed normal histology with numerous seminiferous tubules containing spermatozoa concentrated in the lumen (fig. 2A, B and C). Testicular organ-to-body weight ratio was also not altered by the extract (Table 4). These results provided evidence that subacute administration of the plant extract exerted no adverse effect on testicular function and fertility in rats.

WBC and its differentials (like lymphocytes and neutrophils) and other haematological parameters are measurable indices of the blood, which can be used to evaluate hematopoietic function ${ }^{[34]}$. WBC's are essential for the protection of the animal against foreign invaders. Elevation in their levels is indicative of response to an immunological challenge. Neutrophils 
TABLE 4: B. PINNATUM LEAF EXTRACT CAUSES NO EFFECT ON KIDNEY- AND TESTIS-BODY WEIGHT RATIOS IN WISTAR RATS

\begin{tabular}{lcc}
\hline \multirow{2}{*}{ Dose $(\mathrm{mg} / \mathrm{kg})$} & \multicolumn{2}{c}{ Organ-to-body weight ratio $\left(\times 10^{-3}\right)$} \\
\cline { 2 - 3 } & \multicolumn{1}{c}{ Kidney } & Testis \\
\hline Control & $713.30 \pm 71.49$ & $753.30 \pm 192.90$ \\
62.5 & $838.00 \pm 169.10$ & $796.00 \pm 168.40$ \\
125 & $746.00 \pm 70.47$ & $938.00 \pm 185.50$ \\
\hline
\end{tabular}

Data expressed as mean \pm SEM, $\mathrm{n}=6$ animals per group
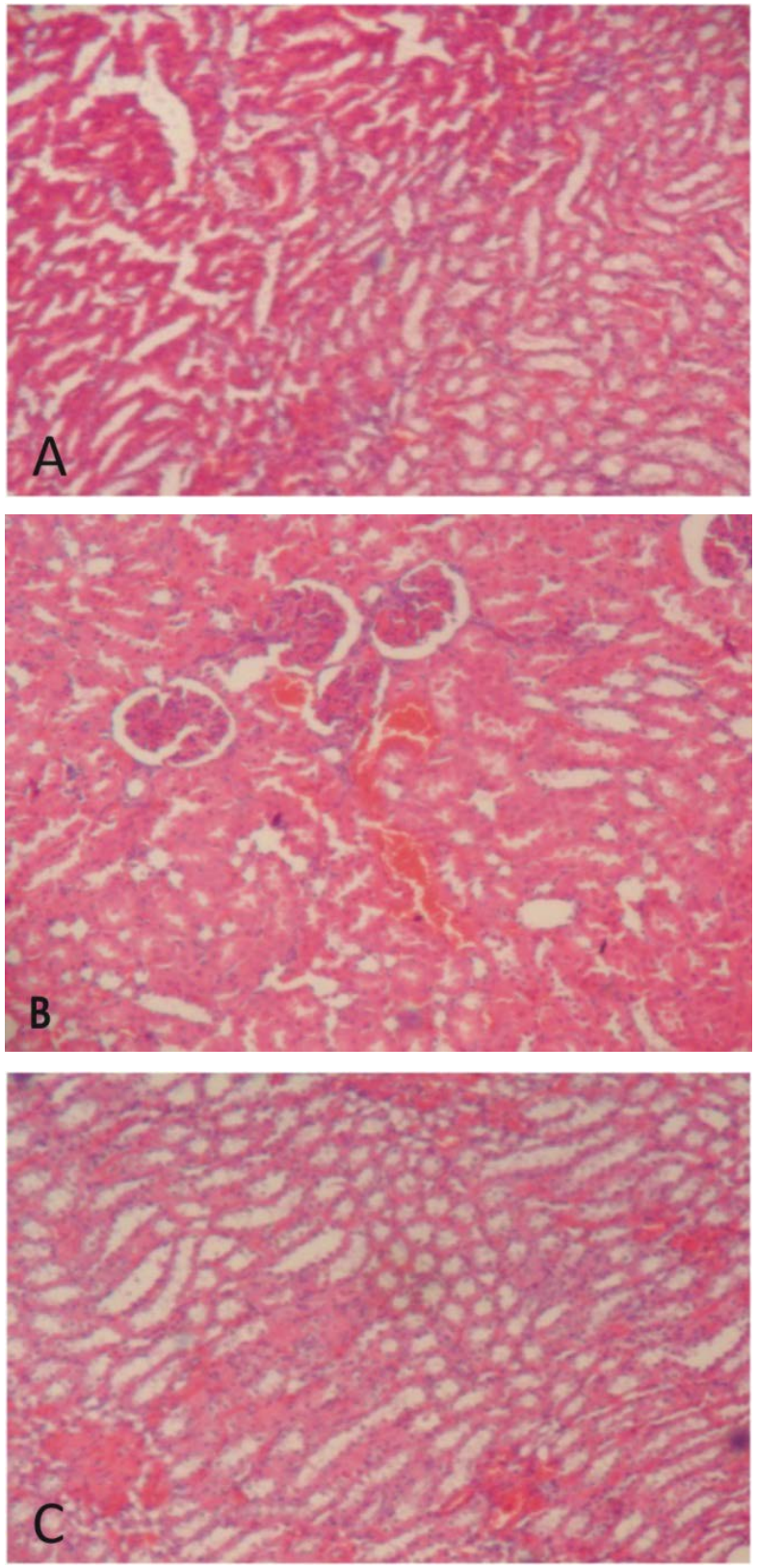

Fig. 1: Photomicrographs of kidney following sub-acute administration of aqueous leaf extract

A: (Control): shows normal architecture and structure with numerous glomeruli and tubules, and blood vessels lined by endothelial cells; B: (62.5 mg/kg AQBP treated group): Shows normal architecture and structure with numerous glomeruli and tubules; C: (125 mg/kg AQBP treated group): Shows normal architecture and structure with numerous glomeruli and tubules; Magnification of $(\times 400)$, and stained with $H$ and $E$

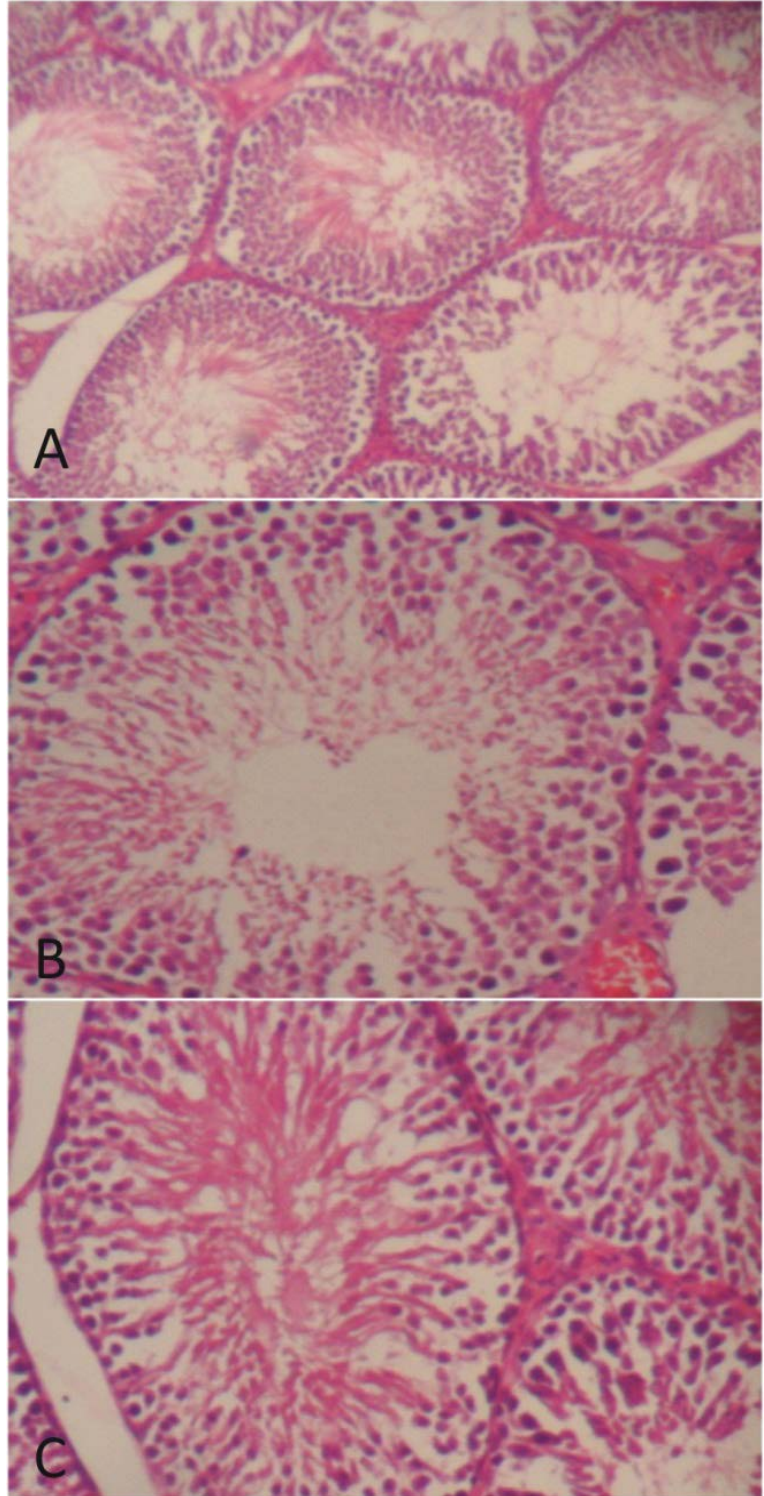

Fig. 2: Photomicrographs of testis following sub-acute administration of aqueous Bryophyllum pinnatum leaf extract (AQBP)

A: (Control): Shows normal histology of testis with normal seminiferous epithelium, normal spermatogenic cell differentiation, and numerous spermatozoa in the lumen; $B$ : (62.5 mg/kg AQBP treated group): Shows normal architecture of testis with normal spermatogenic cell differentiation, and normal sperm production; C: $(125 \mathrm{mg} / \mathrm{kg}$ AQBP treated group): Shows normal architecture of testis with normal seminiferous epithelium, and normal sperm production; aqueous Bryophyllum pinnatum leaf extract; Magnification of $(\times 400)$, and stained with $H$ and $E$

are important phagocytic cells normally elevated in the early inflammatory response ${ }^{[36,37]}$, while lymphocytes are subtypes of leucocytes critically essential for providing cell mediated immunity. Our results showed that total WBC and lymphocyte counts were increased in extract $(165 \mathrm{mg} / \mathrm{kg})$ treated group, but only the effect on WBC was significant $(\mathrm{P}<0.05)$, when compared to 
TABLE 5: EFFECTS OF SUB-ACUTE ADMINISTRATION OF AQUEOUS B. PINNATUM LEAF EXTRACT ON SOME HEMATOLOGICAL PARAMETERS IN WISTAR RATS

\begin{tabular}{lcccc}
\hline Dose $(\mathrm{mg} / \mathrm{kg})$ & PCV $(\%)$ & WBC $\left(\times 10^{6} / \mathrm{ml}\right)$ & Neutrophils $(\%)$ & Lymphocytes $(\%)$ \\
\hline Control & $42.25 \pm 1.32$ & $2.95 \pm 0.37$ & $50.00 \pm 9.13$ & $50.00 \pm 9.13$ \\
62.5 & $42.25 \pm 1.32$ & $3.00 \pm 0.40$ & $27.50 \pm 1.09$ & $72.50 \pm 11.09$ \\
125 & $39.50 \pm 2.10$ & $4.93 \pm 0.22^{* *}$ & $20.00 \pm 5.74$ & $75.00 \pm 5.00$ \\
\hline
\end{tabular}

Data expressed as mean \pm SEM, $n=6$ animals per group. * ${ }^{*}$ Significant at $P<0.01$. PCV: packed cell volume, WBC: white blood cells

the control (Table 5). Neutrophil count was significantly reduced, while PCV was not altered in treated groups compared to control group (Table 5). Inhibition of neutrophils suggested that the plant might depress primary immune response, including inflammation. Previously, the aqueous extract of B. pinnatum has been demonstrated to possess antiinflammatory ${ }^{[7,13]}$ and immunosuppressive activities ${ }^{[36]}$. These properties could partly be related to the neutrophilic effect observed in this study. Additionally, the results indicated that the plant might not cause anaemia as it did not affect PCV. Earlier, Ufelle et $a l^{\left[{ }^{[3]}\right.}$ had also reported elevation of WBC following sub-acute treatment of methanol extract of $B$. pinnatum, which is consistent with our results, but reported elevation of PCV. In another study, sub-acute oral treatment of a single large dose $(2 \mathrm{~g} / \mathrm{kg})$ of the plant has been reported to produce similar haematological effects as obtained in the present study, except on WBC and neutrophils, which were reported to be unaffected ${ }^{[31]}$. We attributed these different results to different concentrations that were used in the studies; however, more studies are necessary to provide better understanding of the mechanisms involved. Further, non-characterization of the extracts is a limitation of this study and it is recommended that further studies to identify and establish the chemical structure(s) of the active components be taken up.

Overall, these results indicated that $B$. pinnatum could be considered to have relatively low toxicity profile, with respect to the organs evaluated in this study. Subacute administration of the plant might exert no adverse effect on the kidney and testis, but could potentially depress neutrophilactivity in rats. The phytoconstituents of the plant obtained in this study included flavonoids, saponins, tannins and alkaloids, which were similar to those reported earlier ${ }^{[15,20]}$. Flavonoids and other important antioxidant constituents of the plant were known free radical scavengers, capable of preventing oxidative cell damage and reducing oxidative stress. Other components like saponins and triterpenoids could be toxic to certain cellular components. Different effects that were observed might therefore be related to the numerous phytochemical compounds contained in the extract.

\section{Acknowledgement:}

The authors thank Dr. Maxwell Azubuike for support in statistical analysis.

\section{Conflict interests:}

The authors declare that there is no conflict of interest.

Financial support and sponsorship:

Nil.

\section{REFERENCES}

1. Wong W. Some folk medicinal plants from Trinidad. Econ Bot 1976;30:103-42.

2. Oliver-Bever B. Medicinal plants in tropical West Africa. III. Anti-infection therapy with higher plants. J Ethnopharmacol 1983;9:1-83.

3. Gill LS. Ethno-medical uses of plant in Nigeria. Benin, Nigeria: Uniben Press; 1992.

4. Okafor JC, Ham R. Identification, utilization and conservation of medicinal plants in South Eastern Nigeria. Issues in African biodiversity support programme; 1999.

5. Chopra RN, Nayar SI, Chopra II. Glossary of Indian Medicinal Plants. New Delhi: NISCIR (CSIR); 2002.

6. Ghasi S, Egwuib C, Achukwu PU, Onyeanusi JC. Assessment of the medical benefit in the folkloric use of Bryophyllum pinnatum leaf among the Igbos of Nigeria for the treatment of hypertension. Afr J Pharm Pharmacol 2011;5:83-92.

7. Almeida AP, Da Silva SAG, Souza MLM, Lima LMTR, Rossi-Bergmann B, Goncalves de Moraes VL, et al. Isolation and chemicals analysis of a fatty acid fraction of Kalanchoe Pinnata with a potent lymphocyte suppressive activity. Planta Medica 2000;66:134-7.

8. Salahdeen HM, Yemitan O. Neuropharmacological effects of aqueous leaf extract of Bryophyllum pinnatum in mice. Afr $\mathrm{J}$ Biomed Res 2006;9:101-7.

9. Afzal M, Gupta G, Kazmi I, Rahman M, Afzal O, Alam J, et al. Antiinflammatory and analgesic potential of a novel steroidal derivative from Bryophyllum pinnatum. Fitoterapia 2012;83:853-8.

10. Akinpelu DA. Antimicrobial activity of Bryophyllum pinnatum leaves. Fitoterapia 2000;71:193-4.

11. Okwu DE, Nnamdi FU. Two novel flavonoids from Bryophyllum pinnatum and their antimicrobial Activity. J Chem Pharm Res 2011;3:1-10.

12. Supratman U, Fujita T, Akiyama K, Hayashi H, Murakami A, Sakai H, et al. Anti-tumor promoting activity of bufadienolides from Kaianchoe pinnata and $K$. daigremontiana $\mathrm{x}$ tubiflora. Biosci Biotechnol Biochem 2001;65:947-9. 
13. Pal S, Chaudhuri AKN. Studies on the anti-ulcer activity of a Bryophyllum pinnatum leaf extract in experimental animals. J Ethanopharmacol 1991;33:97-102.

14. Supratman U, Fujita T, Akiyama K, Hayashi H. New insecticidal bufadienolide, bryophyllin $\mathrm{C}$, from Kalanchoe pinnata. Biosci Biotechnol Biochem 2000;64:1310-12.

15. Ojewole JAO. Antinociceptive, anti-inflammatory and antidiabetic effects of Bryophyllum pinnatum (Crassulaceae) leaf aqueous extract. J Ethnopharmacol 2005;99:13-9.

16. Asiedu-Gyekye IJ, Antwi DA, Bugyei KA, Awortwe C. Comparative study of two kalanchoe species: total flavonoid, phenolic contents and antioxidant properties. Afr J Pure Appl Chem 2012;6:65-73.

17. Ojewole JAO. Antihypertensive properties of Bryophyllum pinnatum (Lam.) Oken leaf extracts. Am J Hypertens 2002;15:34

18. Okwu DE, Josiah C. Evaluation of the chemical composition of two Nigerian medicinal plants. Afr J Biotech 2006;5:357-61.

19. Cao H, Xia J, Xu D, Lu B, Chen G. The separation and identification of the flavonoids from the leaves of Bryophyllum pinnatum. Zhong Yao Cai 2005;28:988-90.

20. Yamagishi T, Haruna M, Yan XZ, Chang JJ, Lee KH. Antitumor agents, 110, Bryophyllin B, a novel potent cytotoxic bufadienoiide from Bryophyllum pinnatum. J Nat Prod 1989;52:1071-9.

21. Marriage PB, Wilson BG. Analysis of the organic acids of Bryophylum pinnatum. Can J Biochem 1971;11:1500-2.

22. Osujih M. Exploration of the frontiers of tradomedical practices: basis for development of alternative medical healthcare services in developing countries. J R Soc Health 1993;113:190-4.

23. Saad B, Abdelmoneim I, Adam G, Elghazali L. Traditional Arab herbal medicine, evidence-based complementary and alternative medicine. J Ethnopharmacol 2006;90:625-7.

24. Larrey DA, Chan JE, Ngogang JY, Cai X, Vinson JA. Antioxidant Capacity of some Herbs/Spices: A Comparative Study of two Methods. J Agric Food Chem 1994;53:6819-24.

25. Jagessar RC, Allen R. Phytochemical screening and atomic absorption spectroscopic studies of solvent type extract from leaves of Terminalia catappa, (Almond). Acad Res In 2012;3:17-26.

26. https://www.ccac.ca/Documents/Standards/Guidelines/Farm Animals.pdf.

27. Tietz NW, Pruden EL, Siggard-Anderson O. Electrolytes, blood gasses and acid base balance in textbook of clinical chemistry. Philadelphia: Saunders; 1986.

28. Weatherbum MW. Phenyl-hypochlorite reaction for determination of ammonia. Anal Chem 1967;39:971-4.

29. Ochei O, Kolhatker A. Medical Laboratory Science, Theory and Practice. 5th ed. New Delhi: Tata McGraw-Hill Publishing Company Limited; 2002.

30. Amelar RD, Dublin L, Schoenfeld C. Semen analysis: An office technique. Urology 1973;2:606-11.

31. Ozolua RI, Idogun SE, Tafamel GE. Acute and subacute toxicological assessment of aqueous leaf extract of Bryophyllum pinnatum (Lam.) in Sprague-Dawley rats. Am J Pharmacol Toxicol 2010;5:145-51.

32. Michael B, Yano B, Sellers RS, Perry R, Morton D, Roome $\mathrm{N}$, et al. Evaluation of organ weights for rodent and nonrodent toxicity studies: A review of regulatory guidelines and a survey of current practices. Toxicol Pathol 2007;35:742-50.

33. Biswas SK, Chowdhury A, Das J, Hosen SMZ, Uddin R, Rahaman MS. Literature review on pharmacological potentials of Kalanchoe pinnata (Crassulaceae). Afr J Pharm Pharmacol 2011;5:1258-62.

34. Obianime AW, Aprioku JS, Esomonu CTO. Antifertility effects of aqueous crude extract of Ocimum gratissimum L. leaf in male mice. J Med Plants Res 2010;4:809-16.

35. Aprioku JS, Obianime AW. Evaluation of the effects of Citrus aurantifolia (Lime) juice in lead-induced haematological and testicular toxicities in rats. Pharmacologia 2014;5:36-41.

36. Guyton AC. Textbook of Medical Physiology. 11th ed. Philadelphia: Elsevier Saunders; 2006.

37. Zhang W, Fievez L, Cheu E, Bureau F, Rong W, Zhang Y, et al. Antiinflammatory effects of formoterol and ipratropium bromide against acute cadmium-induced pulmonary inflammation in rats. Eur J Pharmacol 2010;628:171-8. 